\title{
Molecular Docking Analyses of Few Chalcone Analogues In To the Ligand Binding Domain of EGFR in Search of Anticancer Agents
}

\author{
PurraBuchi Reddy, Madhusudhana Reddy M.B. And Ramakrishna Reddy K. \\ Department of Chemistry RevaUniversity, Bengluru, Karnataka, India
}

Abstract:
Cancer is one of the leading cause mortality
across the globe and it is public health and
economic issue. Further existing agents used in
treatment of cancer are known for serious
undesirable effects. Hence there is urgent need
of agents which will take care of cancerous
pain and will exhibit minimal undesirable
effects. In the present work molecular docking
analyses of few chalcones in to the ligand
binding domain of epidermal growth factor
receptor in search of anticancer agent is
reported. The 3D structures of all the 15
designed chalcone derivatives were sketched
using chemsketch and geometric optimization
with 1000 iteration was carried out using
universal force field in Argus Lab until each
ligand converged to lowest energy state and
saved in .pdb format for docking process.
Receptor, (Epidermal Growth Factor Receptor
tyrosine kinase domain with $4-$
anilinoquinazoline inhibitor Erlotinib), Pdb-id:
1 M17 was undertaken for the analyses.
Molecular modeling and docking approaches
have been implemented to compare the
binding efficiency between the indigenous
inhibitor Erlotinib, designed 15 chalcone
derivatives with EGFR kinase.

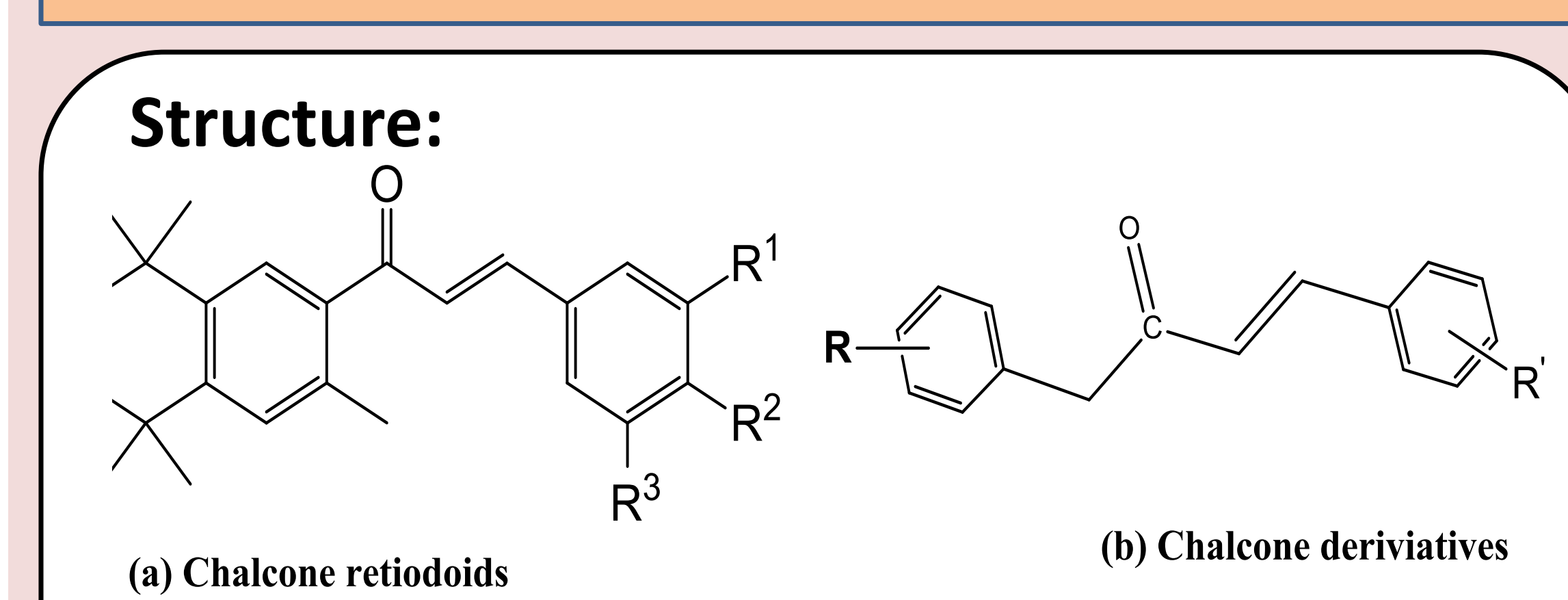

Fig.1. Structures of chalcones derivatives having anticance activity
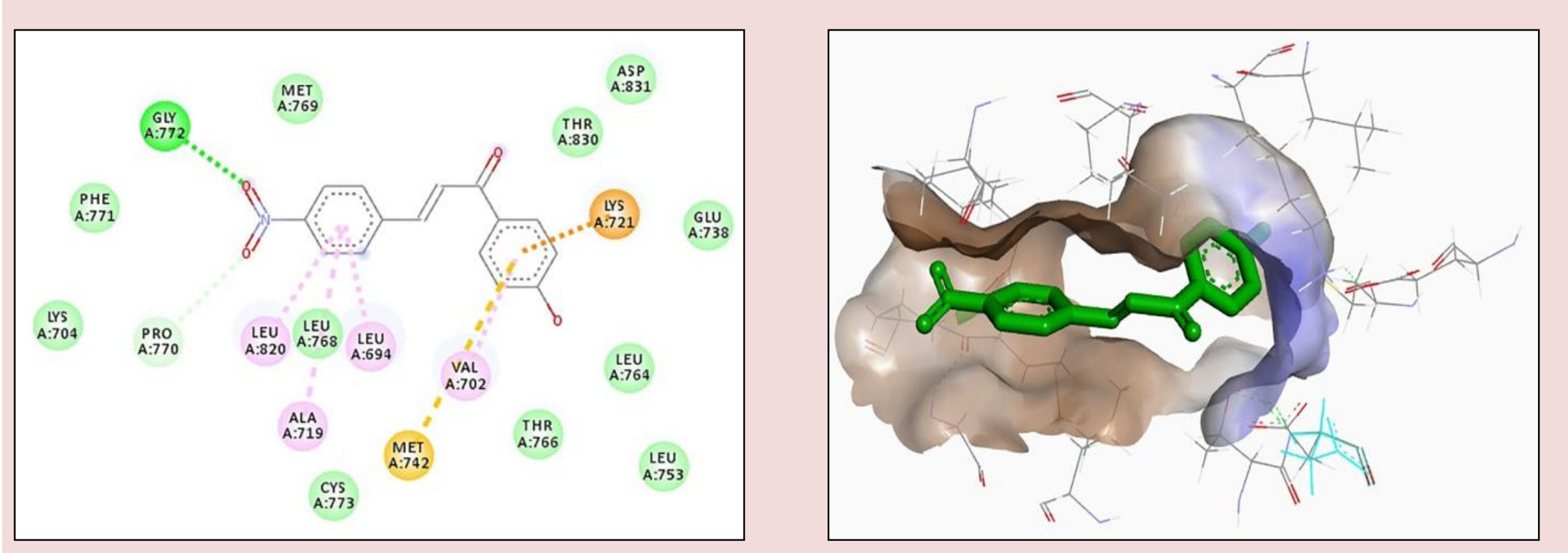

Fig 2: CHL2 -

interaction with EGFR with EGFR in hydrophobic cavity

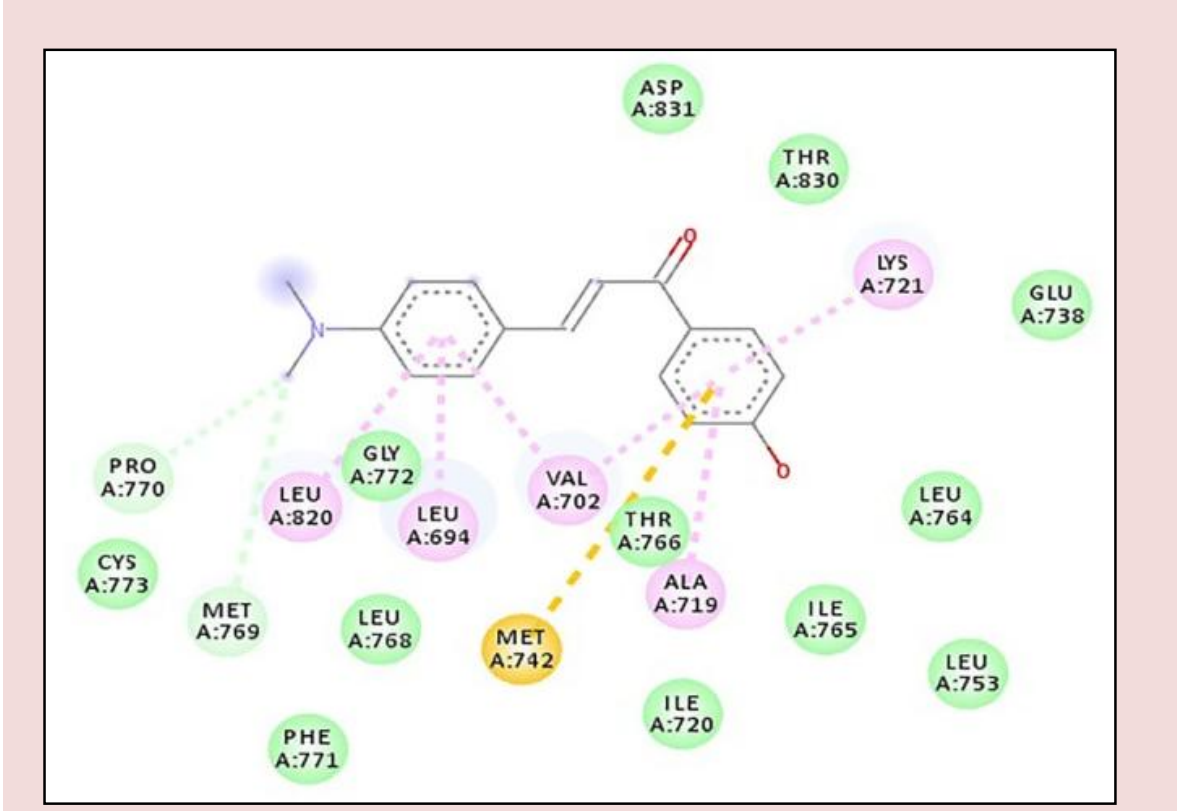

Fig 4: CHL3 -

interaction with EGFR

\section{Introduction}

Chalcones are secondary metabolite precursors of flavonoids and isoflavonoids, which are commonly found in edible plants. These comprise one of the main classes of naturally occuring small molecules with very promising anticancer activity. There are a number of reports on the activity of chalcones against several cell lines including prostate 1 and breast cancer 2 in low nanomolar concentrations [1]. Novel compounds of chalcone- retinoids Fig. 1. (a), have been synthesized and evaluated for their cytotoxic activity against HT-29, a colon cancer cell-lines[2] Chalcone analogues consisting of substituted benzene with groups such as methoxy, halogens, and hydroxyl, result in molecules with poten anticancer activity against colon cancer cell lines exhibiting $\mathrm{IC}_{50}$ value below $1 \mu \mathrm{M}$ [3]. Chalconesis a useful structural motif for displaying potent antitumor activity. Epidermal growth factor receptor is kind of protein kinases, were proved to be a viable target for anticancer drug development [4]. In addition, EGFR-TK is one of the most important kinases that plays a fundamental role in signal transduction pathways [5Peng-Cheng et al., 2010). EGFR and its ligands, epidermal growth factor (EGF) and transforming growth factor- $\alpha$ (TGF- $\alpha$ ) have been implicated in numerous tumors of epithelial origin [6 Ullrich and Schlessinger, 1990)

In-silico modeling and docking studies:

The 3D structures of all the 15 designed chalcone derivatives were sketched using chemsketch and geometric optimization with 1000 iteration was carried out using universal force field in Argus Lab until each ligand converged to lowest energy state and saved in .pdb format for docking process Receptor, (Epidermal Growth Factor Receptor tyrosine kinase domain with 4-anilinoquinazoline inhibitor Erlotinib), Pdb-id: 1M17 was undertaken for the analyses. Molecular modeling and docking approaches have been implemented to compare the binding efficiency between the indigenous inhibitor Erlotinib, designed 15 chalcone derivatives with EGFR kinase of Chalcone derivative to EGFR.

At binding site region, the search space were defined to include residues of the related active sites within the grid size of $X 48 A^{\circ} \times Y 32 A^{\circ} \times Z$ $28 \mathrm{~A}^{\circ}$ and center value with $X 22.104 \mathrm{~A}^{\circ} \times \mathrm{Y}-0.12 \mathrm{~A}$ $X \quad Z$ 53.165 ${ }^{\circ}$, water molecules and cocrystallized ligands were removed.

flexibility: no more than 9 rotatable bonds), drug likeness is calculated using Lipinski rule of five.

\begin{tabular}{|c|c|c|c|c|}
\hline \multirow[t]{2}{*}{ Ligand } & \multirow[t]{2}{*}{ Chemical Structure } & \multirow{2}{*}{$\begin{array}{c}\text { Docking } \\
\text { energy } \\
\mathrm{kcal} / \mathrm{mo} \\
\text { । }\end{array}$} & \multicolumn{2}{|c|}{$\begin{array}{l}\text { Interaction with amino acids in } \\
\text { the Ligand binding domain }\end{array}$} \\
\hline & & & Hydrogen bond & Pi-interaction \\
\hline $\begin{array}{l}\text { Erlotini } \\
\text { b }\end{array}$ & & -7.6 & $\begin{array}{l}\text { Met 769, Gly } \\
772\end{array}$ & $\begin{array}{l}\text { Leu } 694, \text { Val 702, } \\
\text { Ala 719, Lys } 721, \\
\text { Leu } 820\end{array}$ \\
\hline CHL1 & & -7.5 & Thr 766 & $\begin{array}{l}\text { Phe 699, Val 702, } \\
\text { Lys 721, Asp } 831\end{array}$ \\
\hline CHL2 & & -7.7 & Pro 770 , Gly 772 & $\begin{array}{l}\text { Leu 694, Ala 719, } \\
\text { Val 702, Lys 721, } \\
\text { Met 742, Leu } 820\end{array}$ \\
\hline CHL3 & & -7.5 & $\begin{array}{l}\text { Met 769, Pro } \\
770\end{array}$ & \begin{tabular}{|l} 
Leu 694, Val 702, \\
Ala 719, Lys 721 , \\
Met 742 , Leu 820
\end{tabular} \\
\hline CHL4 & & -7.3 & Thr 766 & $\begin{array}{l}\text { Phe 699, Val 702, } \\
\text { Lys 721, Asp } 831\end{array}$ \\
\hline CHL5 & & -7.5 & -- & $\begin{array}{l}\text { Leu } 694 \text {, Ala 719, } \\
\text { Lys } 721 \text {, Met 742, } \\
\text { Leu } 820\end{array}$ \\
\hline CHL6 & & -7.8 & Glu 738 & $\begin{array}{l}\text { Leu 694, Lys 721, } \\
\text { Met 742, Leu } 820\end{array}$ \\
\hline CHL7 & & -7.2 & Thr 766 & $\begin{array}{l}\text { Phe 699, Val 702, } \\
\text { Lys 721, Asp } 831\end{array}$ \\
\hline CHL8 & & -7.7 & |- & $\begin{array}{l}\text { Phe 699, Val 702, } \\
\text { Lys 721, Met 742, } \\
\text { Leu 764, Asp } 831\end{array}$ \\
\hline CHL9 & & -7.6 & Met 769 & $\begin{array}{l}\text { Leu 694, Ala 719, } \\
\text { Lys 721, Met 742, } \\
\text { Leu } 820\end{array}$ \\
\hline CHL10 & & -7.6 & -- & $\begin{array}{l}\text { Phe 699, Val 702, } \\
\text { Lys 721, Met 742, } \\
\text { Asp 831 }\end{array}$ \\
\hline CHL11 & & -7.9 & Met 769 & $\begin{array}{l}\text { Leu } 694 \text {, Ala 719, } \\
\text { Lys 721, Leu 764, } \\
\text { Leu } 820\end{array}$ \\
\hline CHL12 & & -7.9 & -- & $\begin{array}{l}\text { Leu 694, Phe 699, } \\
\text { Val 702, Ala 719, } \\
\text { Lys 721, Met 742, } \\
\text { Asp 931 } \\
\end{array}$ \\
\hline CHL13 & & -7.7 & $\begin{array}{l}\text { Ala 719, Leu } \\
\text { 764, Thr } 766\end{array}$ & $\begin{array}{l}\text { Phe 699, Val 702, } \\
\text { Lys 721, Asp } 831\end{array}$ \\
\hline CHL14 & & -6.9 & Lys 721 , Thr 766 & $\begin{array}{l}\text { Phe 699, Val 702, } \\
\text { Lys 721, Met 742, } \\
\text { Asp 831 }\end{array}$ \\
\hline CHL15 & & -8.1 & Met 769 & $\begin{array}{l}\text { Leu 694, Val 702, } \\
\text { Ala 719, Lys 721, } \\
\text { Met 742 }\end{array}$ \\
\hline
\end{tabular}

Conclusion

As per the study we conclude, the advancement in the computational methodologies, in the present work attempt of in-silico molecular modeling studies, molecular docking analyses and assessment of toxicity by using computational tools is reported with the hope of reducing above mentioned threats.

Key References
1. N. Lawrence, A. T. McGown, Synthesis and biological evaluation of retinoid-chalcones as inhibitors of colon cancer cell growth Curr. Pharm. Des. 11(2005) 1679-1683

P. Shiby, S. Nanioo, A.M. Rimando, Synthesis and biological evaluation of chalcones as inhibitors of cancer, Bioorg Med. Chem. Lett, 20 (2010) 7387-7392

S. M. Cassia, P. Shiby, S. Nanjoo, A. M. Rimando, Synthesis and biological S. M. Cass $P$. Shiby S. Nanjoo, A. M. Rimitors of colon cancer cell growth Bioorg. Med. Chem. Lett., 20 (2010) 7385-7387

Wu et al 2012; Levitzki, 2012. Cheng et al 2011) Kinases are involved Wu et al., 2012; Levitzki, 2012; Cheng et al., 2011). Kinases are involved types of malignancies (Roymans and Slegers, 2001; Malumbres and Barbacid, 2007 